\title{
We Shall Dance, Unless You Choose Not To
}

\author{
Nathan Mannebach*
}

\section{INTRODUCTION}

Ideally, a trip to the pharmacist cures any feelings of nausea, but for many Americans just thinking about that trip makes their stomach churn. This is because of the outrageous prices most consumers find when they go to the checkout counter. Biologics, an innovative new type of drug engineered from living organisms, cost an average of $\$ 45$ per day. ${ }^{1}$ Luckily, not all types of drugs are this expensive. Pharmaceutical drugs, such as Tylenol, only cost an average of $\$ 2$ per day. ${ }^{2}$ This is largely due to a strong market for generic pharmaceutical drugs which saved Americans "over a trillion dollars in healthcare costs between 2002 and 2011."3 Congress set out to improve the generic biologic market in 2009 by passing the Biologics Price Competition and Innovation Act (BPCIA), ${ }^{4}$ but consumers have yet to see much benefit. ${ }^{5}$

The main reason consumers have not seen a significant price drop is time - the longer the BPCIA has been in effect the more prices will decline because the Food and Drug Administration (FDA) will approve more generic biologics. However, courts are beginning to interpret the most important provisions of the BPCIA, and how well the judges do their job will have a huge effect on the healthcare market. If the judges do their job correctly, the BPCIA could save the United States \$250

\footnotetext{
* J.D. Candidate, 2017, University of Kansas School of Law; B.S. Biological Systems Engineering, 2014, University of Nebraska-Lincoln. I would like to thank Dr. Andrew Torrance for his helpful feedback and guidance throughout the writing process, as well as Andrew Kershen and the members of the University of Kansas Law Review for their hard work and assistance in publishing this Note. I would also like to thank my family and friends (particularly the Boys of 1015 Illinois) for their constant encouragement and support. Finally, Luke Hangge deserves credit for providing comments that did not ruin my paper.

1. Joseph P. Fuhr Jr., Lower Price, Greater Access to Life-Saving Drugs, THE HiLl, July 30, 2014, http://thehill.com/blogs/congress-blog/healthcare/213702-lower-price-greater-access-to-lifesaving-drugs.

2. $I d$.

3. Id.

4. Title VII of the Patient Protection and Affordable Care Act, Pub. L. No. 111-148, 124 Stat. 119, 804-28 (2010) (codified in scattered sections of 21, 28, 29, 35, and 42 U.S.C.).
}

5. See Fuhr, supra note 1. 
billion between 2014 and 2024. ${ }^{6}$ In July 2015, the Federal Circuit decided Amgen v. Sandoz, ${ }^{7}$ a case of first impression interpreting 42 U.S.C. $\S 262(l)$, the section which is colloquially termed the "Patent Dance." "This decision has huge implications on how quickly and efficiently intellectual property disputes are handled under the BPCIA. The more quickly and efficiently parties solve these disputes, the sooner consumers will see generic biologics at the pharmacy at prices that do not upset the stomach.

This Note establishes that the Federal Circuit erred in holding that companies can decide not to participate in the Patent Dance because the plain language of the statute, along with legislative intent, demand that the Patent Dance be mandatory.

Part II begins by explaining the key terms of the BPCIA, including defining what a biologic is, how a biologic can be biosimilar to another biologic, and why it is important to have an abbreviated pathway to FDA approval. Part II.B describes the Hatch-Waxman Act, which is the legislation that allowed companies to make generic versions of pharmaceutical drugs, and which was used as a model by the authors of the BPCIA. Part II.C explains the Patent Dance in detail, including the procedures each company must follow to comply with it and why it is important. Part II.D establishes the similarities and differences between the Hatch-Waxman Act and the BPCIA and why the BPCIA is an improvement on the Hatch-Waxman Act. Finally, Part II.E analyzes the decision of the Federal Circuit in Amgen v. Sandoz and begins the discussion of why the court erred in not making the Patent Dance mandatory.

Part III opens with a brief overview of the legislative history of the BPCIA, including a list of the important versions of the bill that were not turned into law. Parts III.A.1-6 analyze each of those versions: the Second and Third Waxman Bills, the Inslee Bill, the Eshoo Bill, the Kennedy, Clinton, Hatch, and Enzi Bill, and the FTC Report, in more depth. In each of these descriptions there is also an explanation of how those versions differ from the final BPCIA legislation and how those

6. Press Release, Steve Miller, Express Scripts, The $\$ 250$ Billion Potential of Biosimilars Apr. 23, 2013, http://lab.express-scripts.com/insights/industry-updates/the-\$250-billion-potential-ofbiosimilars.

7. Amgen Inc. v. Sandoz Inc., 794 F.3d 1347 (Fed. Cir. 2015), cert. granted, 84 U.S.L.W. 3549 (U.S. Jan. 13, 2017) (No. 15-1195).

8. Carl J. Minniti III, Comment, Sandoz v. Amgen: Why Current Interpretation of the Biologic Price Competition and Innovation Act of 2009 Is Flawed and Jeopardizes Future Competition, 97 J. PAT. \& TRADEMARK OfF. SOC'Y 172, 178 (2015). 
differences show that the BPCIA's authors intended a mandatory Patent Dance.

Part III.B describes how the court should have interpreted the Patent Dance provisions of the BPCIA, while adhering to legislative history, the plain meaning of the statute, and the rule against surplusage. Finally, Part III.C recommends three different ways congressional members could rewrite the BPCIA to ensure the Patent Dance is interpreted as mandatory.

\section{BACKGROUND}

\section{A. What Is the BPCIA?}

The BPCIA provides an abbreviated pathway to FDA approval for biosimilar biologics. A biologic is defined in the BPCIA as a "virus, therapeutic serum, toxin, antitoxin, vaccine, blood, blood component or derivative, allergenic product, [or] protein" used to improve health in human beings. ${ }^{9}$ This essentially means that if a medical product results from a living organism it meets the definition of a biologic. ${ }^{10}$ Scientists engineer these products from living organisms by creating "uniform and unique 'cell lines' of a specific bacterium, mammalian organ, or another cellular source." "This is an exceedingly difficult process requiring indepth knowledge of cell biology and protein synthesis. ${ }^{12}$

Not all biologics qualify for the BPCIA's abbreviated pathway, only those that are "biosimilar" to a "reference" product, otherwise known as a biologic that has already received FDA approval. ${ }^{13}$ This is important because every new prescription drug marketed in the United States must have FDA approval. ${ }^{14}$ Drug manufacturers acquire FDA approval for

\footnotetext{
9. 42 U.S.C. $\S 262(i)(1)$ (2012).

10. Jordan Paradise, Follow-On Biologics: Implementation Challenges and Opportunities, 41 SetON HaLl L. ReV. 501, 502 (2011).

11. Bryan A. Liang, Regulating Follow-On Biologics, 44 HARV. J. ON LEGIS. 363, 369 (2007).

12. See id.

In biologics production, scientists create uniform and unique "cell lines" of a specific bacterium, mammalian organ, or another cellular source. This process begins by introducing the DNA that codes for the protein product of interest into the cell line; this DNA travels to the cellular nucleus, and the cellular machinery from the cell line reads the DNA and creates the protein. Id. (citations omitted).

13. See Sara Margolis, Note, Destined for Failure? An Analysis of the Biologics Price Competition and Innovation Act of 2009, 2013 COLUM. BUS. L. REV. 209, 211 (2013).

14. What Is the Approval Process for a New Prescription Drug?, U.S. FoOD \& DRUG ADMIN. [hereinafter Approval Process], http://www.fda.gov/AboutFDA/Transparency/Basics/ucm194949 .htm (last visited Jan. 16, 2017).
} 
their new drugs by first completing animal testing, and then moving on to a series of human clinical trials, referred to as phases. ${ }^{15}$

The first phase of human clinical trials examines several safety measures and the most frequent side effects of the new drug by testing it in healthy volunteers. ${ }^{16}$ The next phase begins determinations on the effectiveness of the new drug by testing it in human subjects possessing the disease or condition the new drug attempts to alleviate. ${ }^{17}$ Finally, if both of the prior studies were successful, the FDA allows the new drug sponsor to test its drug on a significantly larger population to make final findings on the drug's safety and effectiveness. ${ }^{18}$

Upon completion of all required testing, the drug's sponsor provides the FDA with an application for approval in the form of either a New Drug Application (NDA) or a Biologics License Application (BLA). ${ }^{19}$ If the new drug is a pharmaceutical drug, discussed infra, the sponsor files a NDA, while if the new drug is a biologic the sponsor files a BLA. ${ }^{20}$ The two applications are largely similar and both must include the results from testing, information showing the manufacturer can adequately and accurately manufacture the drug, and a suggested label for the drug. The label must include "necessary information about the drug, including uses for which it has been shown to be effective, possible risks, and how to use it.",21

The abbreviated pathway created by the BPCIA allows a biosimilar manufacturer to skip these standard FDA requirements and instead rely on the animal testing and human clinical trials already completed by a reference product sponsor. This saves the biosimilar manufacturer millions of dollars and years of research because the brand name biologic's sponsor has already undertaken the studies. ${ }^{22}$ A biosimilar manufacturer can only do this if it can prove that its biologic is biosimilar to a reference product that already has approval.

A biologic is considered biosimilar to a reference product when it is:

15. The FDA's Drug Review Process: Ensuring Drugs Are Safe and Effective, U.S. FoOD \& DRUG ADMIN., http://www.fda.gov/drugs/resourcesforyou/consumers/ucm143534.htm (last visited Jan. 16, 2017).

16. Id.

17. Id.

18. Id.

19. Approval Process, supra note 14.

20. Id.

21. Id.

22. Amgen Inc. v. Sandoz Inc., No. 14-cv-04741, 2015 U.S. Dist. LEXIS 34537, at*2 (N.D. Cal. Mar. 19, 2015), aff'd in part, vacated in part, 794 F.3d 1347 (Fed. Cir. 2015), cert. granted, 84 U.S.L.W. 3549 (U.S. Jan. 13, 2017) (No. 15-1195). 
(1) "highly similar to the reference product notwithstanding minor differences in clinically inactive components" and (2) the differences in "safety, purity, and potency" between the two products are negligible. ${ }^{23}$ Although a biosimilar manufacturer does not have to complete the standard clinical trials required of a new biologic it must still complete enough studies to show that it meets these two requirements. Much of the preceding discussion applies to the Hatch-Waxman Act as well because Congress modeled the BPCIA on the Hatch-Waxman Act. ${ }^{24}$

\section{B. Generic Pharmaceutical Drug Pathway}

Congress passed the Hatch-Waxman Act in 1984 to provide a pathway to FDA approval for generic pharmaceutical drugs. ${ }^{25}$ In much the same way that biosimilar manufacturers can skip an extensive FDA approval process, so can manufacturers of generic pharmaceutical drugs. Pharmaceutical drugs are made from wholly inanimate matter that reacts identically every time the same stimuli are introduced. ${ }^{26}$ These drugs have a low molecular weight; their structures have been completely characterized; they are chemically stable; and they are mostly nonimmunogenic. $^{27}$ By comparison, biologics are considerably larger; they cannot be fully characterized; they are chemically unstable and sensitive to external stimuli; and they are potentially immunogenic. ${ }^{28}$ For example, Procrit, a common biologic, is 200 times larger than acetaminophen, a common small-molecule drug. ${ }^{29}$

There is also a major difference in how the two types of drugs are manufactured. ${ }^{30}$ Because pharmaceutical drugs are small, they can generally be manufactured using "well-established, consistent" methods. ${ }^{31}$ However, biologics "are not uniformly produced through traditional manufacturing," and even a small change in chemical

\footnotetext{
23. 42 U.S.C. § 262(i)(2)(A), (B) (2012).

24. Minniti III, supra note 8, at 177.

25. Drug Price Competition and Patent Term Restoration (Hatch-Waxman) Act of 1984, Pub. L. No. 98-417, 98 Stat. 1585 (codified as amended in scattered sections of 21, 28, and 35 U.S.C.).

26. See Liang, supra note 11, at 367.

27. Paul J. Declerck, Biologicals and Biosimilars: A Review of the Science and Its Implications, 1 GeNerics \& BIOSIMILARS INITIATIVE J. 13, 13 (2012).

28. Id.

29. Charles Davis, Note, Take Two and Call Congress in the Morning: How the Biologics Price Competition and Innovation Act May Fail to Prevent Systemic Abuses in the Follow-On Biologics Approval Process, 81 GEO. WASH. L. REV. 1255, 1262-63 (2013).

30. Id. at 1263.

31. Id.
} 
structure can have a huge impact on the biologic's efficacy. ${ }^{32}$ Biologics are made using living cells and "no two cell lines, developed independently, can be considered identical." 33 Furthermore, "the quality attributes of the final [biologic] inherently vary with the type of host cell, the growth conditions, the purification process, the formulation, and the storage conditions." 34 This places a huge importance on method patents to protect manufacturing of biologics that is not necessary with pharmaceutical drugs. ${ }^{35}$ The ease with which pharmaceutical drugs are copied has created a huge market for generics using the Abbreviated New Drug Application (ANDA) laid out in the Hatch-Waxman Act. ${ }^{36}$

The ANDA pathway is actually easier to comply with than the biosimilar pathway because a generic pharmaceutical drug only has to show that its active ingredients are the same, ${ }^{37}$ the "route of administration, the dosage form, and the strength of the new drug are the same as those of the listed drug," 38 and the labeling is the same. ${ }^{39}$ The ANDA pathway pays no regard to the differences in the safety or effectiveness between the brand name product and the generic followon. ${ }^{40}$ Differences in safety and effectiveness can be disregarded because once the active ingredients, administration route, dosage form, and strength of the generic pharmaceutical are shown to be identical to the brand name product, there are no differences in safety and effectiveness. $^{41}$

Congress's stated goal in enacting the BPCIA and the HatchWaxman Act was to create a market for generic drugs that cost substantially less than the brand name versions they are biosimilar or identical to. ${ }^{42}$ Congress addressed this goal for pharmaceutical drugs under the Hatch-Waxman Act which has allowed generics to enter the

\footnotetext{
32. Id.

33. Declerck, supra note 27 , at 13 .

34. Id. at 14 .

35. See infra notes 55-58 and accompanying text.

36. 21 U.S.C. $\S 355(j)(2012)$.

37. Id. $\S 355(\mathrm{j})(2)(\mathrm{ii})(\mathrm{I}-\mathrm{III})$.

38. Id. $\S 355(\mathrm{j})(2)(\mathrm{iii})$.

39. Id. $\S 355(\mathrm{j})(2)(\mathrm{v})$.

40. See id. $\S 355(\mathrm{j})(2)$ (setting out all the requirements for a follow-on generic drug that does not provide for any extra safety or effectiveness documentation).

41. See Declerck, supra note 27 , at 14 ("For a generic . . . drug, it is sufficient to demonstrate comparable quality ... with a reference (innovator) product to obtain regulatory approval.").

42. Letter from Rep. Anna G. Eshoo et al. to President Barack Obama 1 (Oct. 14, 2011), http://patentdocs.typepad.com/files/house-letter.pdf ("Following in the footsteps of the earlier HatchWaxman Act, which ushered in a new era of competition and affordable drugs, the [BPCIA] would for the very first time allow patients access to generic, cheaper versions of biologic drugs.").
} 
market " 25 percent lower than the branded drug's price. The price discount can rise to 80 percent with multiple generic entrants." 43 As of February 2017, the FDA has only approved four drugs as biosimilar under the BPCIA; the first biosimilar went to U.S. market at a $15 \%$ wholesale price reduction. ${ }^{44}$ Commentators are bearish on whether the BPCIA will ever have the same price-reducing impact on biologics that the Hatch-Waxman Act has had on pharmaceutical drugs. ${ }^{45}$ Although the BPCIA is based on the Hatch-Waxman Act, and they both attempt to achieve the same result, there are significant differences between the two in terms of their patent provisions.

\section{What Is the Patent Dance?}

The Patent Dance describes how intellectual property issues that arise between the reference product sponsor and the biosimilar applicant should be handled unless both parties agree to another method. ${ }^{46}$ The Dance begins when a biosimilar applicant submits its application to the FDA. ${ }^{47}$ At this time, the biosimilar applicant provides its application and information on its manufacturing process to the reference product sponsor, and may provide it to any third-party patent owners, all of whom must keep this information confidential. ${ }^{48}$

Upon receiving the application, the reference product sponsor uses this information to determine which patents it reasonably believes the biosimilar applicant will infringe upon by going to market. ${ }^{49}$ The reference product sponsor sends this list of patents back to the biosimilar

43. Michael S. Wroblewski et al., Fed. Trade Comm'n, Emerging Health Care ISSUES: FOLLOW-ON BIOLOGIC DRUG COMPETITION 12 (2009), https://www.ftc.gov/sites/ default/files/documents/reports/emerging-health-care-issues-follow-biologic-drug-competitionfederal-trade-commission-report/p083901biologicsreport.pdf.

44. Steven Ross Johnson, Sandoz Launches Sale of Biosimilar Zarxio, Modern HeALTHCARE (Sept. 3, 2015), http://www.modernhealthcare.com/article/20150903/NEWS/150909949 (announcing biosimilar Zarxio); Press Release, U.S. Food \& Drug Admin., FDA Approves Inflectra, a Biosimilar to Remicade (Apr. 5, 2016), http://www.fda.gov/NewsEvents/Newsroom/ PressAnnouncements/ucm494227.htm (announcing FDA approval of biosimilar Inflectra); Press Release, U.S. Food \& Drug Admin., FDA Approves Erelzi, a Biosimilar to Enbrel (Aug. 30, 2016), http://www.fda.gov/NewsEvents/Newsroom/PressAnnouncements/ucm518639.htm (announcing FDA approval of biosimilar Erelzi); Press Release, U.S. Food \& Drug Admin., FDA Approves Amjevita, a Biosimilar to Humira (Sept. 23, 2016), http://www.fda.gov/NewsEvents/Newsroom/ PressAnnouncements/ucm522243.htm (announcing FDA approval of biosimilar Amjevita).

45. E.g., Margolis, supra note 13, at 222-36.

46. 42 U.S.C. $\S 262(l)(1)(\mathrm{A})(2012)$.

47. Id. $\S 262(l)(1)(\mathrm{B})(\mathrm{i})$.

48. $\quad I d . \S 262(l)(1)(\mathrm{B})(\mathrm{ii}),(l)(\mathrm{B})(\mathrm{iii}),(l)(2)$.

49. Id. $\S 262(l)(1)(\mathrm{D})$. 
applicant who analyzes the list, and, for each patent, asserts that the patent is "invalid, unenforceable, or will not be infringed" by going to market. ${ }^{50}$ Alternatively, the biosimilar applicant can agree not to go to market until certain patents have expired. ${ }^{51}$ Finally, for every patent that the biosimilar applicant believes is invalid, unenforceable, or will not be infringed, the reference product sponsor must respond with why the patent is valid, enforceable, or will be infringed. ${ }^{52}$ This back and forth communication is where the name Patent Dance comes from, and it is important that the parties participate in it for several reasons. ${ }^{53}$

First, the parties use these lists to determine which patents will be involved in litigation. ${ }^{54}$ Having access to these lists and the biosimilar applicant's application are especially important for method patents. ${ }^{55}$ Method patents in this case would cover the specific manufacturing process used by the reference product sponsor, which are important because the best way to make a biosimilar biologic is to use the same or a very similar manufacturing process. ${ }^{56}$ Without this information on the biosimilar applicant's manufacturing process, the reference product sponsor will not know if their method patents have been infringed. ${ }^{57}$ In such a case, the reference product sponsor would risk Rule 11 sanctions under the Federal Rules of Civil Procedure if it initiates a patent infringement suit on the method patents because the processes used by the biosimilar applicant could be totally different. ${ }^{58}$

Second, participation in the Patent Dance "open[s] the courthouse doors." "59 The BPCIA amended the Patent Act to allow for a constructive act of infringement when the biosimilar applicant submits an application, insuring that litigation can occur quickly and efficiently. ${ }^{60}$ Without this constructive act of infringement the courts would have no jurisdiction to hear the case because there would be no case or controversy. ${ }^{61}$ The

\footnotetext{
50. $\quad I d . \S 262(l)(3)(\mathrm{B})(\mathrm{ii})(\mathrm{I})$.

51. Id. §262(l)(3)(B)(ii)(II).

52. Id. $\S 262(l)(3)(\mathrm{C})$.

53. Minniti III, supra note 8, at 178-79.

54. Id.

55. Leslie-Anne Maxwell et al., BPCIA: How Long Is The Party, And Do I Have To Dance?, LAw360, Mar. 24, 2015, http://www.law360.com/articles/631861/bpcia-how-long-is-the-party-anddo-i-have-to-dance.

56. Jeremiah J. Kelly \& Michael David, No Longer "If," But "When": The Coming Abbreviated Approval Pathway for Follow-On Biologics, 64 FOOD \& DRUG L.J. 115, 119-20 (2009).

57. Maxwell et al., supra note 55.

58. Id.; see FED. R. CIV. P. 11 (prescribing sanctions for frivolous actions).

59. Minniti III, supra note 8, at 179.

60. Id. (discussing amendments to 35 U.S.C. § 271(e)).

61. Valley Forge Christian Coll. v. Ams. United for Separation of Church \& State, 454 U.S.
} 
Patent Act typically withholds jurisdiction until a party "without authority makes, uses, offers to sell, or sells any patented invention." 62 The biosimilar applicant might not be able to make, use, offer to sell, or sell their biosimilar until the reference product sponsor's exclusive sale period is almost expired. As soon as the reference product sponsor's exclusive sale period expires, the biosimilar applicant wants to start making its biosimilar, not have to wait several more years for litigation to end. The BPCIA ensures the parties do not have to wait so long to initiate a suit.

It is important to note that the Patent Act also allows for a constructive act of infringement when:

[T] he applicant for the application fails to provide the application and information required ... if the purpose of such submission is to obtain approval under such Act to engage in the commercial manufacture, use, or sale of a drug, veterinary biological product, or biological product claimed in a patent or the use of which is claimed in a patent before the expiration of such patent. ${ }^{63}$

This provision could be construed to satisfy the case or controversy requirement when a biosimilar applicant decides not to participate in the Patent Dance, but the provision cannot be construed this way without serious negative consequences. Using this provision to bring a declaratory judgment action introduces the risk of Rule 11 sanctions against reference product sponsors because they would not have the information necessary to bring a good faith suit.

\section{Hatch-Waxman Act's Similarities and Differences to the BPCIA}

The BPCIA is based, in part, on the Hatch-Waxman Act, but there are some significant deviations, especially in the patent provisions. ${ }^{64}$ The Hatch-Waxman Act ensures the general public, including generic drug makers, have the information they need regarding patents listed in the Orange Book. ${ }^{65}$ The Orange Book tells generic drug makers all of

\footnotetext{
464, 472 (1982) (citations omitted) (noting that there must be an "actual or threatened injury" fairly traceable to the conduct of the defendant).

62. 35 U.S.C. $\S 271$ (a) (2012).

63. Id. §271(e)(2)(C)(ii).

64. Krista Hessler Carver et al., An Unofficial Legislative History of the Biologics Price Competition and Innovation Act of 2009, 65 FOOD \& DRUG L.J. 671, 815-16 (2010); Davis, supra note 29 , at 1259 .

65. See Carver et al., supra note 64 , at 815 .
} 
the patents that a brand name manufacturer has on its products. ${ }^{66}$ This is significantly different than the BPCIA where all patent disclosures are done in private, subject to strict confidentiality requirements. ${ }^{67}$ The BPCIA's system could allow the biosimilar applicant and the reference product sponsor to "collude against third parties or enter pay-to-delay settlements." 68

One important advantage reference product sponsors receive under the BPCIA, which they would not receive under the Hatch-Waxman Act, is how method patents are handled. The Hatch-Waxman Act does not cover method patents, and they cannot even be listed in the Orange Book. $^{69}$ The BPCIA specifically states that manufacturing information shall be exchanged during the Patent Dance, and these patents can clearly be asserted in litigation. ${ }^{70}$ This is unsurprising when one considers the differences in manufacturing the two types of drugs. ${ }^{71}$ The authors of the BPCIA realized that manufacturing of generic pharmaceuticals was standard, requiring only a "formulaic stepwise approach," 72 and the method patents would not be that important. Whereas, some brand name biologics manufacturers will almost certainly depend on method patents to ensure they retain exclusivity.

Finally, the differences in how the patent litigation proceeds are perhaps the largest departure between the two bills. The Hatch-Waxman Act does not have anything as extensive as the Patent Dance, and all constructive-infringement litigation stems from a "Paragraph IV" certification which states that the generic manufacturer does not believe the brand name manufacturer's patents are valid or they will not be infringed by manufacture of the generic. ${ }^{73}$ After this certification has been made, the parties proceed to litigation using "traditional patent infringement analysis." 74 As was extensively noted in the Patent Dance discussion, the authors of the BPCIA attempted to script every part of biosimilar patent litigation. ${ }^{75}$

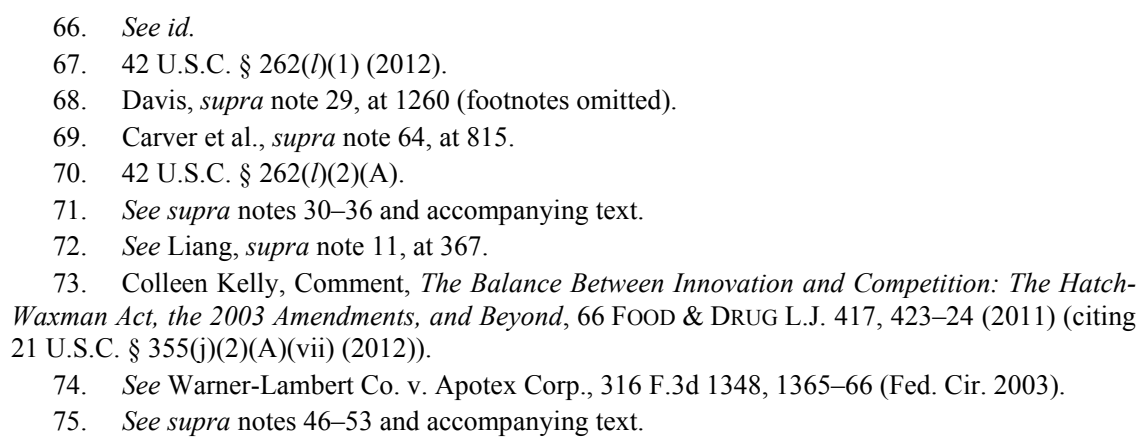


This final difference is the most salient to this Note because it helps explain why Congress wanted the Patent Dance to be mandatory. The authors of the BPCIA specifically acknowledged they were modeling the BPCIA on the Hatch-Waxman Act, and yet the two pieces of legislation differ greatly in how patent litigation proceeds. One logical conclusion from this is that the authors of the BPCIA were concerned that under the Hatch-Waxman patent litigation provisions, biosimilar applicants would not have access to method patents before filing an infringement suit. ${ }^{76}$ The complexity of manufacturing biologics makes method patents vital to biologic manufacturers who want to protect their investment and could often be the only patent they have. ${ }^{77}$ Under the Hatch-Waxman patent provisions, a biologic manufacturer would have to file suit against the biosimilar manufacturer without knowing how the biologic is manufactured. $^{78}$ This would open them up to Rule 11 sanctions if the manufacturing processes used by the biosimilar and biologic manufacturers are completely different. ${ }^{79}$

The authors of the BPCIA recognized this as a threat to the incentive to create new biologics so they deviated from the Hatch-Waxman Act and designed stricter rules. Patents are widely considered more important to the pharmaceutical industry as compared to other industries because of the high R\&D costs and ease of free riding. ${ }^{80}$ The Patent Dance insures that if a biologic manufacturer accepts the risk of developing a new drug, that manufacturer will be able to protect against free riding. When the biosimilar applicant is not forced to participate in the Patent Dance, the litigation basically reverts to the same provisions used in the Hatch-Waxman Act. If Congress wanted this, they would have adopted the Hatch-Waxman patent provisions word for word.

Commentators writing about the Patent Dance before Amgen $v$. Sandoz discussed the provision as either "required," "requirements for biosimilar applicants," or "requires a process of information exchange." However, the Federal Circuit reached a different result by finding that

\footnotetext{
76. See supra notes $54-58$ and accompanying text.

77. See supra notes 54-58 and accompanying text; see also supra notes 30-36 and accompanying text.

78. See supra note 54-58 and accompanying text.

79. See supra notes 54-58 and accompanying text.

80. Henry Grabowski, Patents, Innovation and Access to New Pharmaceuticals, 5 J. INT'L ECON. LAW 849, 850-53 (2002).

81. Minniti III, supra note 8, at 178; Paradise, supra note 10, at 507; Donna M. Gitter, Informed by the European Union Experience: What the United States Can Anticipate and Learn from the European Union's Regulatory Approach to Biosimilars, 41 Seton Hall L. ReV. 559, 568 (2011).
} 
the Patent Dance was completely optional.

\section{E. Amgen v. Sandoz}

In Amgen v. Sandoz, the Northern District of California District Court interpreted a key provision of the BPCIA, finding that a biosimilar applicant can choose not to participate in the Patent Dance. ${ }^{82}$ The district court found that the biosimilar applicant could opt out of the Patent Dance because the BPCIA explicitly defined what the consequences for doing so would be in 42 U.S.C. $\S 262(l)(9)(C) .{ }^{83}$ The district court stated that " $[t]$ he BPCIA's plain language and overall statutory scheme support a reading that renders [the Patent Dance] entirely permissible." ${ }^{, 4}$

The case was appealed by Amgen Inc. to the Federal Circuit where the district court's ruling was reviewed de novo and the Patent Dance decision was affirmed. ${ }^{85}$ The Federal Circuit began by discussing the use of "shall" in several sections of the statute ${ }^{86}$ but specifically in one part which reads as follows: "When a [biosimilar] applicant submits an application under subsection (k), such applicant shall provide... confidential access to the information required to be produced pursuant to paragraph (2) and any other information that the [biosimilar] applicant determines, in its sole discretion, to be appropriate...."87 The court apparently agreed with Sandoz's argument that this is merely a "condition precedent to engaging in the information-exchange process of paragraphs $(l)(3)$ through $(l)(6)$, not a mandatory requirement in all circumstances." 88

The court admitted that the plain language of the statute requires participation in the Patent Dance "when an applicant chooses the abbreviated pathway." 89 This creates a criterion in the word "when" that a biosimilar applicant can choose not to meet. ${ }^{90}$ Meaning, if a biosimilar applicant does not choose the abbreviated pathway, it does not have to

82. Amgen Inc. v. Sandoz Inc., No. 14-cv-04741, 2015 U.S. Dist. LEXIS 34537, at *21 (N.D. Cal. Mar. 19, 2015), relevant holding aff'd, 794 F.3d 1347, 1357 (Fed. Cir. 2015), cert. granted, 84 U.S.L.W. 3549 (U.S. Jan. 13, 2017) (No. 15-1195). The court also looked at when notice of commercial marketing can be given, but this Note will only discuss the Patent Dance provisions.

83. Id. at $* 34$.

84. Id. at $* 21$.

85. Amgen Inc. v. Sandoz Inc., 794 F.3d 1347, 1354, 1357 (Fed. Cir. 2015), cert. granted, 84 U.S.L.W. 3549 (U.S. Jan. 13, 2017) (No. 15-1195).

86. Id. at 135455

87. 42 U.S.C. $§ 262(l)(1)(B)(i)(2012)$ (emphasis added).

88. Amgen Inc., 794 F.3d at 1355.

89. Id.

90. Id. 
participate in the Patent Dance. ${ }^{91}$ However, such a reading is misleading because the only way for a biosimilar applicant to actually become a biosimilar applicant is to use the abbreviated pathway. ${ }^{92}$ If a biosimilar applicant is not using the abbreviated pathway, it would not be a biosimilar applicant, it would be undergoing the longer approval process of a reference product; so, the "when" criterion is always met.

After apparently deciding the "when" criterion was not met in Amgen, but not explaining that decision in any way, the court suggested that other sections of the Act make the Patent Dance optional. ${ }^{93}$ The court cited 42 U.S.C. $\S 262(l)(9)(C)$ which states "[i]f a [biosimilar] applicant fails to provide the application and information required under paragraph (2)(A),' then the [reference product sponsor], but not the [biosimilar] applicant, may bring a declaratory judgment action." 94 This is a statutorily created remedy invoked when a biosimilar applicant does not participate in the Patent Dance, and the court said reading the BPCIA any other way would make that remedy section superfluous, which the court wanted to strongly avoid. ${ }^{95}$ This is the same rationale used by the district court, and both decisions ignore the plain language of the statute, ignore the legislative history of the BPCIA, and come to the wrong conclusions on whether the Patent Dance is optional.

The rest of this Note will show how the legislative history of the BPCIA clearly calls for a mandatory Patent Dance, how the Federal Circuit could have construed the statute to comply with the legislative history, and further how Congress could amend the BPCIA to ensure the Patent Dance is mandatory.

\section{ANALYSIS}

Although statutory interpretation usually begins with the plain language of a statute, ${ }^{96}$ the BPCIA's conflicting use of the word "shall" with a remedy for not participating in the Patent Dance creates an ambiguity. When a statute is ambiguous, legislative history becomes a helpful clue in understanding the intent of Congress. ${ }^{97}$ Furthermore,

\footnotetext{
91. $I d$.

92. See supra Part I.A.

93. See Amgen Inc., 794 F.3d at 1355.

94. Id. at 1356 (quoting 42 U.S.C. $§ 262(l)(9)(C)$ (2012)) (first alteration in original).

95. Id.

96. Commc'ns Workers of Am. v. Beck, 487 U.S. 735, 764 (1988) (Blackmun, J., concurring in part and dissenting in part) ("As with any question of statutory interpretation, the starting point is the language of the statute itself.").

97. See Chevron, U.S.A., Inc. v. Nat. Res. Def. Council, Inc., 467 U.S. 837, 842-43, 862-63
} 
differences between any proposed bills and the bill actually enacted by Congress are relevant in interpreting a statute. ${ }^{98}$ In the case of the BPCIA, Congress had several markedly different versions of the Patent Dance to choose from. Representatives Waxman, Inslee, and Eshoo all submitted unique bills to the House while Senators Kennedy, Clinton, Hatch, and Enzi worked together on one bill in the Senate. After considering each of these options, the BPCIA's authors ultimately wrote comprehensive patent provisions into the Act. By examining the relevant alternatives below, this Note will show that the bill's authors chose these comprehensive provisions for a reason, and never intended for the Patent Dance to be optional.

\section{A. Legislative History}

\section{Second Waxman Bill}

H.R. 1038, known as the Second Waxman Bill, would allow the biosimilar applicant to request patent information from the reference product sponsor after which the reference product sponsor would have 60 days to reply with a list of patents that it "believes in good faith" relate to the product at issue. ${ }^{99}$ The reference product sponsor had to provide all patents claiming "the approved biological product, any method of using such product, any component of such product, or any method or process of manufacturing such product or component." 100

Any time after the biosimilar applicant received the patent information it could, but did not have to, notify the reference product sponsor of its application and submit a notice to the reference product sponsor that stated the factual and legal basis for why a patent is invalid, unenforceable, or would not be infringed. ${ }^{101}$ Also included must be one or more jurisdictions where the biosimilar applicant consented to suit. ${ }^{102}$ Finally, the bill explicitly stated "[a]n applicant or prospective applicant for a comparable biological product under this subsection may not be compelled, by court order or otherwise, to initiate the procedures set

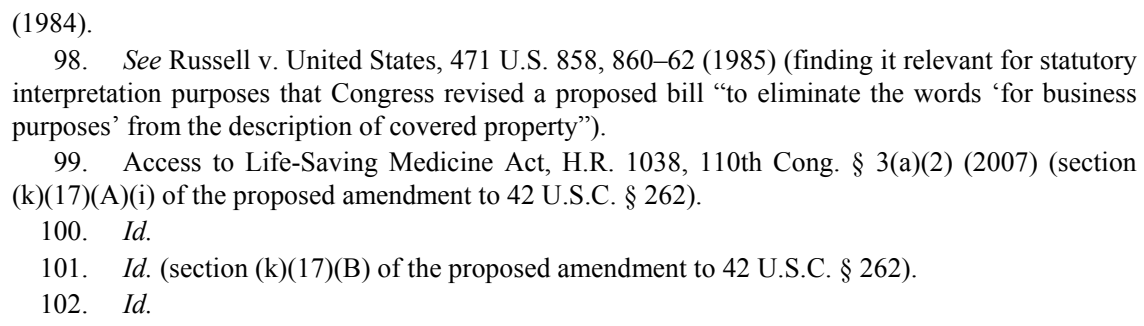

98. See Russell v. United States, 471 U.S. 858, 860-62 (1985) (finding it relevant for statutory interpretation purposes that Congress revised a proposed bill "to eliminate the words "for business purposes' from the description of covered property").

99. Access to Life-Saving Medicine Act, H.R. 1038, 110th Cong. § 3(a)(2) (2007) (section (k)(17)(A)(i) of the proposed amendment to 42 U.S.C. $\S 262$ ).

100. Id.

101. Id. (section (k)(17)(B) of the proposed amendment to 42 U.S.C. $\S 262$ ).

102. Id. 
forth in this paragraph."

The Second Waxman Bill essentially provided for a simplified version of the BPCIA. It allowed for the parties to exchange patent information, but most importantly it explicitly made every step of the process optional. For example, the biosimilar applicant "may" request patent information; ${ }^{104}$ upon receiving this patent information the biosimilar applicant "may" reply with reasons why there will be no infringement; ${ }^{105}$ and finally, the last paragraph of the relevant section literally states that the entire process is optional.

This is in sharp contrast to the BPCIA, which states the biosimilar applicant "shall" provide the reference product sponsor with its application and any information on its manufacturing process, the reference product sponsor "shall" respond with patents that could reasonably be asserted, after which the biosimilar applicant "shall" reply with why there will not be infringement, and the reference product sponsor "shall" state why there will in fact be infringement. ${ }^{106}$ Also, there is no separate paragraph making these disclosures explicitly optional.

This sharp contrast in language cannot be accidental. The authors of the BPCIA had more than enough options for how to make the BPCIA's patent provisions optional by looking at the plain language of the Second Waxman Bill and adopting it. They could have simply substituted "may" everywhere they had "shall," and the plain language would have been clearly permissive. Furthermore, by deciding not to adopt the explicit provision in the Second Waxman Bill making the entire process permissive, the authors provided strong evidence that they intended it to be mandatory.

\section{Inslee Bill}

H.R. 1956, known as the Inslee Bill, is widely considered the simplest of all the biosimilar bills because it left out many of the features found in the other bills including pediatric market exclusivity and patent provisions. ${ }^{107}$ The Inslee Bill did not provide any guidance for how the

\footnotetext{
103. Id. (section (k)(17)(E) of the proposed amendment to 42 U.S.C. § 262).

104. Id. (section (k)(17)(A)(i) of the proposed amendment to 42 U.S.C. $\$ 262$ ).

105. Id. (section (k)(17)(B) of the proposed amendment to 42 U.S.C. $\$ 262)$.

106. See 42 U.S.C. $\S 262(l)(2012)$.

107. See Colleen Tracy \& Christopher Loh, Variations on a Theme: Five Proposed Abbreviated Approval Pathways for Biogenerics, BloOmBerg L. ReP. HeAlth L., Apr. 2009, at 4, http://cache.fitzpatrickcella.com/wp-content/uploads/attachment528.pdf.
} 
reference product sponsor and biosimilar applicant should disclose their patents to each other or how they should conduct patent litigation. ${ }^{108}$ In fact, the bill does not mention the word "patent" a single time. ${ }^{109}$

This is considerably different from the BPCIA, which regulates patent disclosures to the nth degree by providing for an extensive series of back and forth communication. The authors of the final BPCIA legislation must have thought the patent provisions were important or they would have followed the lead of the Inslee Bill and simply ignored any patent provisions. There is a strong statutory presumption against making any section superfluous or even insignificant. ${ }^{110}$ Including so much language on how patent disclosures would proceed, when the authors had the option to not include any provisions at all, clearly shows they wanted to make the section significant, and reading the section as optional does the opposite. Interpreting the Patent Dance as optional makes the entire section insignificant and borderline superfluous because by not following it, biosimilar applicants gain the advantage of filing the suit on their terms.

\section{Eshoo Bill}

H.R. 5629, known as the Eshoo Bill, is very similar to the BPCIA with the main difference being that the BPCIA adds a few more steps to its Patent Dance. The Eshoo Bill states that within thirty days of the Secretary of Health and Human Services accepting the biosimilar applicant's application, the applicant must provide the reference product sponsor with its application including a "detailed description of the biosimilar product, its method of manufacture, and the materials used in the manufacture of the product."111 After receiving the application, the reference product sponsor must respond with a list of patents it believes are "relevant" and explain why these relevant patents would be infringed. ${ }^{112}$

Upon receiving this information, the biosimilar applicant must

108. See Patient Protection and Innovative Biologic Medicines Act of 2007, H.R. 1956, 110th Cong. (2007).

109. See id.

110. TRW Inc. v. Andrews, 534 U.S. 19, 31 (2001) ("It is 'a cardinal principle of statutory construction' that 'a statute ought, upon the whole, to be so construed that, if it can be prevented, no clause, sentence, or word shall be superfluous, void, or insignificant." (quoting Duncan v. Walker, 533 U.S. 167, 174 (2001)).

111. Pathway for Biosimilars Act, H.R. 5629, 110th Cong. § 101(a)(2) (2008) (section (l)(4)(A)(i) of the proposed amendment to 42 U.S.C. § 262).

112. Id. (sections $(l)(4)(\mathrm{A})(\mathrm{ii})$ and $(l)(4)(\mathrm{C})$ of the proposed amendment to 42 U.S.C. § 262). 
respond by either agreeing not to go to market until the relevant patents expire, or stating why the relevant patent will not be infringed or is invalid. ${ }^{113}$ The reference product sponsor then must decide within sixty days whether to sue. ${ }^{114}$ If it decides to do so and the court finds infringement, then the Secretary will not make approval effective until after patent expiry. ${ }^{115}$

Just like the BPCIA, the Eshoo Bill uses the word "shall" each time it refers to the obligations of the reference product sponsor or the biosimilar applicant in regards to patent disclosures. ${ }^{116}$ However, fewer communications between the two parties are required under the Eshoo Bill as compared to the BPCIA. This is important because it means the authors of the BPCIA put even more emphasis on the patent provisions than the most similar bill it could be compared to; so, the authors are even less likely to want those provisions to be seen as insignificant. The court should view the added steps in the BPCIA as an intentional choice that the authors want all parties to comply with.

\section{Third Waxman Bill}

H.R. 1427, known as the Third Waxman Bill, is very similar to the Second Waxman Bill with a few minor changes. This bill does not allow the biosimilar applicant to choose the jurisdiction for the infringement suit. ${ }^{117}$ It also adds a subsection that creates a case or controversy in all Article III courts so infringement suits can be filed pre-marketing. ${ }^{118}$ This bill retains the discretionary language from the previous one that made any participation by the biosimilar applicant completely optional. ${ }^{119}$

This Waxman Bill is important to show that the language in the Second Waxman Bill was not a solitary example of another way the BPCIA could have been written. Instead, it was an example considered

\footnotetext{
113. Id. (section (l)(4)(D) of the proposed amendment to 42 U.S.C. § 262).

114. Id. (section $(l)(5)$ of the proposed amendment to 42 U.S.C. $\S 262)$.

115. Id.

116. Id. (sections (l)(4)(A), (C), and (D) of the proposed amendment to 42 U.S.C. § 262).

117. Compare Promoting Innovation and Access to Life-Saving Medicine Act (Third Waxman Bill), H.R. 1427, 111th Cong. § 3(a)(2) (2009) (section (k)(18)(C) of the proposed amendment to 42 U.S.C. § 262), with Access to Life-Saving Medicine Act (Second Waxman Bill), H.R. 1038, 110th Cong. § 3(a)(2) (2007) (sections (k)(17)(B)(iii), (C) of the proposed amendment to 42 U.S.C. § 262) (requiring the infringement action to take place in one of the judicial districts specified by the applicant).

118. Id. (section $(\mathrm{k})(18)(\mathrm{E})$ of the proposed amendment to 42 U.S.C. $\S 262)$.

119. Id. (section $(\mathrm{k})(18)(\mathrm{F})$ of the proposed amendment to 42 U.S.C. $\S 262)$; see supra note 104 and accompanying text.
} 
in multiple terms but eventually discarded in favor of the mandatory language of the BPCIA.

\section{Kennedy, Clinton, Hatch, and Enzi Bill}

S. 1695, sharing the name BPCIA with the final legislation, is essentially the first draft of the BPCIA. ${ }^{120}$ Because Congress chose this bill for its final legislation, the patent provisions in it are largely the same and were discussed above, ${ }^{121}$ however, there are some important points to note. In the discussion drafts leading up to this bill, Congress was not going to require the biosimilar applicant to provide information on its manufacturing process to the reference product sponsor. ${ }^{122}$ S. 1695 and the BPCIA both include explicit language to the contrary and state that the manufacturing information must be disclosed. ${ }^{123}$

Disclosure of manufacturing information is important because the reference product sponsor needs to know how the biosimilar applicant makes its biologic so it can figure out if there is infringement of any method patents. ${ }^{124}$ By making the Patent Dance optional, the Amgen court has nullified the BPCIA's authors' direct intent to have the parties exchange manufacturing information. ${ }^{125}$ Under the court's current ruling, a biosimilar applicant can copy the reference product sponsor's method patents, opt out of the Patent Dance, and then hope the reference product sponsor does not sue to learn the biosimilar applicant's process in discovery.

The reference product sponsor will want to sue because it believes there is a chance the biosimilar applicant is copying the method patents, but if the reference product sponsor sues and is ultimately wrong then it could face Rule 11 sanctions. This is an unacceptable scenario for reference product sponsors looking to protect their investment, and one that becomes all too likely when the Patent Dance is optional. The nondisclosure of manufacturing information is one of the biggest problems with interpreting the Patent Dance as optional, and here is clear legislative history showing that Congress paid special attention to this issue and ultimately decided that it needed to be in the final bill.

\footnotetext{
120. Biologics Price Competition and Innovation Act of 2007, S. 1695, 110th Cong. (2007).

121. See supra notes $46-53$ and accompanying text.

122. Carver et al., supra note 64, at 756.

123. S. $1695, \S 2(\mathrm{a})(2)$ (section $(I)(2)(\mathrm{A})$ of the proposed amendment to 42 U.S.C. $\S 262) ; 42$ U.S.C. $\S 262(l)(2)(A)(2012)$.

124. See supra notes $30-35$ and accompanying text.

125. See supra notes $82-91$ and accompanying text.
} 
Furthermore, the BPCIA's authors actually considered alternative processes for the exchange of patent information. ${ }^{126}$ The first process they considered, and eventually rejected, was an optional notification system where the two parties could choose whether they wanted to notify each other of relevant patents. ${ }^{127}$ The authors turned that system down in favor of a "mandatory information exchange process." 128 This is nearly conclusive proof that not only did the authors carefully consider alternatives to their final patent provision language, but they also believed that the parties would be required to participate in the Patent Dance.

\section{FTC Report}

One of the final considerations taken into account by Congress before enacting the BPCIA was a report by the Federal Trade Commission (FTC). ${ }^{129}$ One of the main findings the FTC made was that any patent provisions in a biosimilars bill are unnecessary. ${ }^{130}$ The FTC stated that "[a] special pre-approval patent resolution process is unlikely to succeed in raising and resolving all pertinent patent issues prior to FDA approval" because of the numerous and varied patents that protect biological drugs. ${ }^{131}$ Although the FTC's report did not appear to have an impact on the final legislation, the report highlights the fact that Congress had a lot of options to consider before deciding on the patent provisions.

The authors of the BPCIA disagreed with the FTC report because they designed extensive patent provisions. ${ }^{132}$ They put those provisions in because they wanted them to be followed, every time, not simply when the biosimilar applicant decided to comply. If the authors wanted biosimilar applicants to have a choice, they could have heeded the FTC Report, chosen the Inslee Bill, and let the parties decide for themselves. ${ }^{133}$ They did not do that. Furthermore, Congress had the perfect example of how to write an optional Patent Dance-like system in

\footnotetext{
126. Carver et al., supra note 64, at 757.

127. Id.

128. Id. (emphasis added).

129. See Carver et al., supra 64, at 790 (discussing the timing of WROBLEWSKI ET AL., supra note 43 ).

130. WROBLEWSKI ET AL., supra note 43, at viii-ix.

131. Id. at viii.

132. See supra notes $46-63$ and accompanying text.

133. See supra notes $107-109$ and accompanying text.
} 
the two Waxman bills. ${ }^{134}$ Those two bills included a provision that stated the biosimilar applicant did not have to participate in the information exchange. ${ }^{135}$ The authors of the BPCIA did not choose either of those bills.

Congress could have chosen any of these previous bills, in whole or in part, to make up the final legislation; so, it is fair to assume that they picked the patent provisions in the BPCIA for a reason. There is a presumption that Congress did not intend "to enact statutory language that it has earlier discarded in favor of other language."136 The patent provisions in the BPCIA are the most developed and most structured of any of the available options. ${ }^{137}$ The authors wished to set up a thorough step-by-step process requiring the biosimilar applicant and reference product sponsor to fairly and efficiently litigate any disputed patents.

\section{B. Correctly Construing the Patent Dance Provisions}

The court should have construed the BPCIA so that the Patent Dance would be mandatory without making any of the sections superfluous. Statutory interpretation always begins with the plain language of a statute. ${ }^{138}$ As has been noted, the BPCIA specifically states a biosimilar applicant "shall" provide the reference product sponsor with its application and manufacturing information. ${ }^{139}$ Typically, when legislation includes the word "shall," a court equates that word to a mandatory requirement. ${ }^{140}$ However, because the statute appears to offer a remedy for when a biosimilar applicant refuses to provide the required information, it is ambiguous whether "shall" can actually mean mandatory. ${ }^{141}$ Since it is clear from the legislative history that the authors of the BPCIA meant for the Patent Dance to be mandatory, the

\footnotetext{
134. See supra notes 99-103, 117-119 and accompanying text.

135. Id.

136. Nachman Corp. v. Pension Benefit Guar. Corp., 446 U.S. 359, 392-93 (1980) (Stewart, J., dissenting).

137. Compare 42 U.S.C. $\S 262(l)$ (2012) (legislating extensive patent procedures), with H.R. 5629 (Eshoo Bill), 110th Cong. (2008) (legislating patent procedures with several less steps), H.R. 1956 (Inslee Bill), 110th Cong. (2007) (legislating no patent procedures), and H.R. 1038 (Second Waxman Bill), 110th Cong. (2007) (legislating patent procedures with several fewer steps).

138. Commc'ns Workers of Am. v. Beck, 487 U.S. 735, 764 (1988) (Blackmun, J., concurring in part and dissenting in part) ("As with any question of statutory interpretation, the starting point is the language of the statute itself.").

139. 42 U.S.C. $\S 262(l)(2)(A)(2012)$.

140. Emerald Casino, Inc. v. Ill. Gaming Bd., 803 N.E.2d 914, 921 (Ill. App. Ct. 2003).

141. See supra notes $93-95$ and accompanying text.
} 
Federal Circuit should have construed the statute to do that. ${ }^{142}$

A significant part of the court's argument relies on the supposed alternative remedy for not participating in the Patent Dance found in the BPCIA. That subsection reads:

If a [biosimilar] applicant fails to provide the application and information required under paragraph (2)(A), the reference product sponsor, but not the [biosimilar] applicant, may bring an action under section 2201 of title 28 [United States Code] for a declaration of infringement, validity, or enforceability of any patent that claims the biological product or a use of the biological product. ${ }^{143}$

The court concluded that "may" meant the reference product sponsor only had two options if the biosimilar applicant failed to participate in the Patent Dance: the reference product sponsor could choose to bring a declaratory judgment action or not bring any action at all. ${ }^{144}$

The court was concerned that if the Patent Dance was mandatory then there would be no need for that entire section and it would become superfluous. ${ }^{145}$ However, this does not have to be the case; the Patent Dance can be mandatory and that section can still have significance. The correct construction of that section is that it adds an extra right to the reference product sponsor without removing any options. The reference product sponsor "may" choose to bring an immediate declaratory judgment action as the plain language states, it "may" choose to bring no action at all, or the reference product sponsor "may" still choose to enforce the Patent Dance provisions.

This solution ensures that nothing the BPCIA's authors wrote becomes superfluous but still follows their intent that the Patent Dance should be followed except when both parties agree to another method. The statute specifically allows the parties to choose not to follow the Patent Dance provisions if, and only if, both of them agree. ${ }^{146}$ If a biosimilar applicant does not comply with the Patent Dance provisions, then it knows it is opening itself to a declaratory judgment action. If the reference product sponsor decides to bring a declaratory judgment action instead of enforcing the Patent Dance, then the parties are essentially agreeing to traditional litigation. If this is not what the reference product

\footnotetext{
142. See supra notes $132-37$ and accompanying text.

143. 42 U.S.C. § $262(l)(9)(C)(2012)$

144. Amgen Inc. v. Sandoz Inc., 794 F.3d 1347, 1355-57 (Fed. Cir. 2015), cert. granted, 84 U.S.L.W. 3549 (U.S. Jan. 13, 2017) (No. 15-1195).

145. Id. at 1356 .

146. 42 U.S.C. $\S 262(l)(1)(A)(2012)$.
} 
sponsor wants, then it should be free to enforce the Patent Dance because it did not agree to forego those provisions.

The counterargument is that the alternative remedy section under the construction advocated by this Note would not technically become superfluous but would lose all of its importance. The belief is that no biosimilar applicant would choose to forego the Patent Dance, where it has specific rights, in favor of letting the reference product sponsor bring a declaratory judgment action. This would seem to favor the reference product sponsor because it gives them the advantage of deciding when and where to bring the suit. However, Amgen v. Sandoz itself defeats that argument. Sandoz knew when it decided to forego the Patent Dance that Amgen would bring a declaratory judgment action. Sandoz specifically told Amgen to bring a declaratory judgment action in its letter to Amgen informing them of its decision not to participate in the Patent Dance. ${ }^{147}$ Sandoz decided it had more advantages in a declaratory judgment action than under the Patent Dance, or the company would not have made the choice it did. There is no reason to believe other biosimilar applicants would not make the same decisions, and sometimes the reference product sponsor will agree and want to do a declaratory judgment action as well.

Furthermore, 42 U.S.C. $\S 262(l)(9)(C)$ is supposed to be a penalty to the biosimilar applicant for not following the Patent Dance. However, the way the Amgen court has construed the BPCIA it is not a penalty at all; it just allows the biosimilar applicant to choose the litigation method on its own. Adopting the interpretation of this section intended by the BPCIA's authors would make it a penalty because by not complying with the Patent Dance the biosimilar applicant is allowing the reference product sponsor to choose how the litigation proceeds, either the Patent Dance or a declaratory judgment action. Favoring reference product sponsors encourages more innovation in the pharmaceutical industry because these manufacturers know they can protect their discoveries from free riders. When more innovations occur, money is saved on healthcare costs and lives are saved.

\section{Rewriting the Patent Dance}

It will be helpful to briefly consider some ways congressional members could amend the Patent Dance provisions to make their intent certain. They could do this several ways: they could delete 42 U.S.C. $\S$

147. Amgen Inc., 794 F.3d at 1353. 
262(l)(9)(C) so that section would not be in the way of "shall" in the Patent Dance provisions, they could add in another section simply stating the Patent Dance is mandatory, or they could rewrite 42 U.S.C. § $262(l)(9)(C)$ to state the interpretation they originally intended.

Deleting 42 U.S.C. $\S 262(l)(9)(C)$, the statutorily created remedy for nonparticipation in the Patent Dance, would be the least effective way to make the Patent Dance mandatory, but it would still achieve the desired result. Deleting that section would be the least effective method because the section serves some important functions. ${ }^{148}$ However, if this section were deleted then essentially all of the ambiguity in the BPCIA's use of the word "shall" would be removed. The main reason the Amgen court does not find that "shall" means mandatory is because it finds the statute specifically references the possibility that the biosimilar applicant would not comply. Removing this reference would also remove any ambiguity.

The authors already have an example of how to write a provision to make the Patent Dance mandatory by inserting a modified version of the provision from the Waxman Bills. ${ }^{149}$ The provision could read: "An applicant or prospective applicant for a biosimilar biological product under this subsection may [] be compelled, by court order or otherwise, to initiate the procedures set forth in this paragraph."150 This would still not be the best way for the authors to rewrite the BPCIA because it adds extra language that is not necessary, and the court would still have to interpret 42 U.S.C. $\S 262(l)(9)(C)$ which they could interpret incorrectly once again.

Finally, the authors could rewrite 42 U.S.C. $\S 262(l)(9)(C)$ to explicitly state their original intent and what has been called for in this Note. They could accomplish this by adding a clause to the end of 42 U.S.C. $§ 262(l)(9)(C)$ stating: "Alternatively, the reference product sponsor may, by court order or otherwise, require the biosimilar applicant to comply with paragraph (2)(A)." This would have all of the advantages already discussed in this Note, it would comply with legislative intent, and it would unambiguously inform the courts and the biologics industry that the Patent Dance is mandatory.

\footnotetext{
148. See supra Part III.B.

149. See H.R. 1427 (Third Waxman Bill), 111th Cong. § 3(a)(2) (2009) (section (k)(18)(F) of the proposed amendment to 42 U.S.C. § 262).

150. See id.
} 


\section{CONCLUSION}

The Patent Dance provisions of the BPCIA are mandatory. Although the BPCIA's Patent Dance provisions are somewhat ambiguous, when the plain meaning of the statute is combined with legislative intent it is clear the Federal Circuit's ruling that the Patent Dance is optional is misguided. The authors of the BPCIA had an abundance of options to choose from if they wanted a permissive Patent Dance. The discussion drafts leading up to the BPCIA stated that the authors wanted to require participation in the Patent Dance. The use of "shall" and "required" in the statute are plain language indicators of a mandatory provision. Finally, under the correct interpretation of the statute, none of the provisions become superfluous. The BPCIA is an important piece of legislation that will save hundreds of millions of dollars and thousands of lives due to improved access to life-saving medication, but to do that the provisions in it must be construed correctly. 